\title{
Evolution of Lukács' Concept of the Historic Subject-Object and its Modern Significance
}

\author{
Xiaoping $\mathbf{W}^{*}$ \\ Institute of Philosophy, Chinese Academy of Social Sciences, Beijing, China
}

*Corresponding author: Wei Xiaoping, Ph.D. Professor at Institute of Philosophy, Chinese Academy of Social Sciences, Beijing, China, No. 5, Jianguomennei Dajie, Beijing 100732, P. R. China, Tel: (8610) 65582657; Email: weixiaoping@hotmail.com

\section{Conceptual Paper}

Volume 3 Issue 3

Received Date: August 13, 2020

Published Date: September 17, 2020

DOI: $10.23880 /$ phij-16000151

\section{Abstract}

Lukács' research and writing career started around 1920s and ended in 1970s. This was an era when great changes took place in the world situation, and correspondingly the development and change of Lukács' thoughts in his life were also very obvious. Such change in him can be explained from two aspects: first, he lived in a changeful historical era and underwent the transition from capitalist society to socialist society; second, in 1930s he personally experienced the Soviet Union's practice of socialism and read Marx's Economic and Philosophic Manuscripts of 1844, which played a very important role in his later ideological change. This change could be seen in the evolution of his concept of historical subject-object.

Keyword: Class consciousness; Historical subject-object

Lukács' research and writing career started around 1920s and ended in 1970s. This was an era when great changes took place in the world situation, and correspondingly the development and change of Lukács' thoughts in his life were also very obvious. Such change in him can be explained from two aspects: first, he lived in a changeful historical era and underwent the transition from capitalist society to socialist society; second, in 1930s he personally experienced the Soviet Union's practice of socialism and read Marx's Economic and Philosophic Manuscripts of 1844, which played a very important role in his later ideological change. Though Lukács was not associated with the philosophical background of any philosophical school and did not form any philosophical sect, Lukács exerted very important influence in the history of Marxist philosophy and is regarded as one of the main founders of Western Marxism. Among Lukács' thoughts, the most influential one is his concept of historical subjects. However, people seldom notice that with Europe's historical change in the early $20^{\text {th }}$ century, Lukács' concept of historical subjects also underwent meaningful change, which deserves introspection today.

\section{From Specific Class Subjects to Abstract Historical Subjects}

In the early stage of Lukács' development, the main issue facing Europe seen from the perspective of Marxism was to change capitalist society by negation. He thought then that the proletariat's class consciousness seemed to be a decisive factor for whether such revolution could be conducted successfully, so cultivation of class consciousness and arousal of class consciousness became important issues that Lukács was concerned about. This is the main thought reflected in the book History and Class Consciousness.

Lukács' understanding of the historical role of the proletariat's class consciousness followed Hegel's theoretical model to a large extent. In Hegel's opinion, change in the concept of the subject-object refers to the same thing's selfdevelopment. According to Hegel, such thing is an absolute theory, and an absolute concept's self-development derives objects from subjects and then returns to itself at a higher level after the stage of negation. In Lukács' opinion, the 


\section{Philosophy International Journal}

point of departure is the proletariat, but the proletariat can only rise up from an object to a subject through its class consciousness. In this course of rising up, the proletariat's class consciousness is a decisive link. When the proletariat realizes its historical status and role, it can change history on its own initiative and rise up from a historical object to a historical subject, so the historic subject-object unified on proletariat.

Thus, Lukács' concept of class consciousness plays the role of Hegelian self-consciousness. Hegel made externalized objects return to subjects relying on self-consciousness and thus realized unification of historical subjects and objects, while Lukács made the proletariat a unified subject-object of history relying on class consciousness.

Lukács mainly elaborated on class consciousness in the sense of reflective rational thinking activities. In his opinion, class consciousness is, for a whole class, the understanding of its status in social and economic relations and its historical mission, i.e. a class's self-consciousness in the macroscopic sense. However, if a class is conditioned by its own interests only, its class consciousness is also a kind of unconsciousness. In this case, such class is only a passive class unable to associate thoughts about its interests with the whole society.

Therefore, in Lukács' opinion, class consciousness is not just rational understanding of a class's particular status and a class must at the same time understand its own interests in the sense of the whole society's fundamental interests. In other words, "its interests and consciousness enable it to organize the whole of society in accordance with those interests" ${ }^{\prime \prime}$. It actually already goes beyond a class's limitations and turns class-in-itself consciousness into classfor-itself consciousness. Only when such consciousness with self-reflection ability is possessed can the proletariat become a unified subject-object of history and thus accomplish its historical mission.

Lukács further took such class consciousness as a critical factor for eliminating the phenomenon of materialization and thus changing the actual society, so to highlight the subjective role. In light of the theoretical tendency, Marxist historical materialism is very likely to be understood simply from the perspective of materials and from the perspective of economic determinism mechanically. Opposing mechanical economic determinism and emphasizing the subjective role is Lukács' consistent philosophical position.

In his early period, different from the passive view of inactively waiting for opportunities of historical change,

1 Lukács: History and Class Consciousness, ibid, Page 107.
Lukács emphasized the important role of class consciousness in historical change. Lukács had not read Marx's Economic and Philosophic Manuscripts of 1844 then, but he knew Marx's alienation theory from Marx's other early literature. On this basis, Lukács showed the internal logic of human social movement by revealing relations among people concealed by relations among things: first, in the most basic sense, it is a product of people themselves, but shown as material relations; second, such relations among things seem to have been freed from the power of human control and become material movements, but the role of people is still behind them. In Lukács' opinion, only by revealing real human relations behind economic activities can we see the real course of social development. In other words, man as the core and basis of material relations can only be discovered after elimination of such relations' directness.

Lukács' thought above is a comprehensive expression of Marx's two early theoretical frameworks (emergence and disappearance of alienation, and contradictory movement of productive forces and relations of production). In this expression, he highlighted human factors. In his own words, man has become a yardstick for all things and a subjective force in social and historical development; meanwhile, the foundations of human society and history are built through economic categories and methods, thus "deriving the indissoluble fetishistic forms from the primary forms of human relations"2. In other words, in Lukács' opinion, establishment of a society's economic base cannot replace subjective factors propelling social and historical development. These are two different categories with completely different connotations.

However, Lukács did not understand subjective factors' rich meaning in the sense of man's objective relations. He was still under Hegelian speculative philosophy's influence then, taking subjects as a stage reached by objects through self-consciousness. He deemed the proletariat with class consciousness as such a subject. This is a very narrow understanding of the concept of historical subjects. Because the proletariat's class consciousness is only a certain class's rational understanding of itself and its social existence in a certain stage of historical development and is indirect self-making consciousness, the subject it attains with such consciousness only has specific meanings. Lukács also thought himself that his concept of subjects followed Hegel to a large extent. Of course, such understanding also includes the factor of the time background, emphasizing the initiative of the proletariat with class consciousness in the course of

2 Lukács: History and Class Consciousness, The Commercial Press, 1992 Edition, Page 274. 


\section{Philosophy International Journal}

transition from capitalist society to socialist society.

After the victory of the Soviet Union's October Revolution in 1917, Lukács visited the Soviet Union in early 1930s and personally experienced the first large-scale practice of socialism in history. Under the socialist system, the foundations of the exploitation relationship and the phenomenon of polarization in society were eradicated, but under the conditions of public ownership of the means of production, the issue of internal mechanisms of and driving forces behind social development became prominent at a deep level. This is the real context of Lukács' shift of research scope from class consciousness to the issue of ontology of social existence.

Besides, during his stay in the Soviet Union, Lukács read Marx's newly edited and published Economic and Philosophic Manuscripts of 1844 (hereinafter referred to as Manuscripts). These two opportunities brought about great changes in the element of historical subjects receiving Lukács' attention. Marx's Manuscripts freed him not only from Hegel's model of subject-object development, but also from Hegel's theory of subject-objects' three stages. Influenced by the mode of elaboration on alienated labor in Marx's Manuscripts, Lukács no longer took class consciousness as the main medium factor in unification of historical subjects and objects and no longer understood historical subjects from the perspective of class consciousness. Instead, he proceeded from the origin of social existence to understand the issue of historical subjects in terms of man and nature as well as people's objective relations in society and understand people's subjective role in the sense of social practice, while the targets of practice became objects. The meaning of objective subject-object relationship changed.

Instead of understanding and using the concept of subjects from the perspective of a certain class's particular historical mission, he understood it in terms of more extensive objective relations in people's practice, which was related to his experiences in the Soviet Union of course. Meanwhile, his mode of understanding and accepting Marxism underwent a fundamental change. In his early years, he hated capitalism mainly out of moral and ethical considerations, so he took Marxism as a revolutionary tool for reforming real society to a large extent and used it to explain and guide revolutionary activities; in his later years, he accepted the method of objective analysis used by Marx to study real society and then deduce revolutionary theories in a deeper sense. After he read Marx's Economic and Philosophic Manuscripts of 1844, Lukács' understanding and use of the concept of subjects were very close to Marx's method, i.e. elaborating on the emergence and role of man in terms of objective relations.

\section{Deeper Understanding of the Issue of Subjects and Objects}

Lukács' later thoughts on subject philosophy changed greatly from perceiving the relationship between historical subjects and objects with the proletariat as the carrier to understanding the relationship between historical subjects and objects in terms of people's subjective role in objective natural and social relations.

First, he proceeded from the initial emergence of social existence to analyze subject-object differentiation and the rise of subjectivity. In his opinion, the emergence of man's social existence was a fundamental change in the history of natural development. Henceforth, subjects and objects emerged as forms of existence, While there is nothing close to subjectivity in nature. "Objects are under consciousness only in the development of social existence, and thus subjects' initiative emerges" ${ }^{\prime 3}$.

Second, with the change in Lukács' understanding of the relationship between historical subjects and objects, his understanding of the issue of materialization and alienation also changed. In his early years, there was a certain distance between Lukács' concept of the subject-object of history and objective relations in social existence, and he expressed objective relations in social existence with the concept of materialization. His thinking method of understanding objectification of human activities with the concept of materialization was influenced by Marx to some extent. Marx analyzed the phenomenon of materialization in capitalist economic relations with commodities as cells and thought that in capitalist society, human relations were objectified ghostly in the commodity structure and that only through this material barrier could all traces of human relations behind them be perceived.

Dominated by this thinking method, Lukács understood the objectiveness of human activities in the sense of externalization, taking such externalization as something objective and independent of man as opposed to man. Such opposition is manifested in three aspects, i.e. results of human activities and themselves, courses of human activities and themselves, and personalities and humanbeing, which are all alienated as opposed to man. According to Marx, the phenomenon of materialization of commodity relations only revealed the negative side of objective relations of human activities, i.e. the side of opposition or alienation, which was a particular historical phenomenon in capitalist society, while Lukács in his early years equated objectification with

3 Lukács: An Introduction to the Ontology of Social Existence, Huaxia Publishing House, 1989 Edition, Page 267-268. 


\section{Philosophy International Journal}

alienation generally.

Obviously, Lukács neither understood historical subjects in terms of objective relations nor included the phenomenon of externalization into general objective relations. He only used the concept of materialization to reveal the phenomenon of alienation in reality, and further extended the phenomenon of alienation from objectiveness of activities to regularity of activities.

Thus, he thought immediate relations among people were mediated by the objective laws of the production process, which became forms immediately manifesting relations among people. "Man, who is the foundation and the core of all reified relations, can only be discovered by abolishing the immediacy of those relations" ${ }^{4}$. This deduction from objectification and alienation of things to objectification and alienation of laws was intended to reveal the functioning of economic laws in capitalist society as a force beyond human control and resisting man in an attempt to explain the fact that economic crises broke out frequently in capitalist society in the early $20^{\text {th }}$ century.

With the change in Lukács' thoughts about the historic subject-object, his thoughts about material relations and social laws also changed. He began to realize objectification and alienation are two different categories. Objectification itself is not a critic target of criticism because it is only dual in nature: as man's means of conquering the world, it can be either a positive fact or a negative fact. The results of any human practice are manifested as a kind of objectification, so the social phenomenon of objectification in fact cannot be eliminated in human society, while alienation is manifested as conflict between objective relations and man in social existence. In other words, the relationship of alienation emerges only when human nature is oppressed, twisted and harmed in social existence.

Meanwhile, Lukács' understanding of historical subjects also changed fundamentally. Such change caused Lukács to update his thoughts. He deeply felt that he must carry out all studies from the beginning to make his theoretical system realistically significant. So he not only proceeded from the initial origin of human society to analyze formation and differentiation of subjects and objects, but also proceeded from the initial differentiation of subjects and objects to analyze the emergence of historical subjects and their essential features.

In Lukács' view, the existence of human society itself was a precondition of subjects' rise. "(It can be said with

4 Lukács: History and Class Consciousness, ibid, Page 263. ease that first of all) the emergence of social existence was a fundamental change for man, in which procedural change in forms of existence first gave rise to subjects and objects. Things similar to subjects did not exist in the inorganic sphere, to say nothing of playing a role in it. So there is no subject in inorganic existence" 5 .

Then how did human society emerge? It was the result of human labor. People formed relations among them in productive labor and gradually formed society. At the same time, people also became subjects of social existence through labor, and established brand new subject-object relations in the labor process. In Lukács' opinion, man's labor practice is essentially different from animals' instinctive activities for survival in that human labor has the features of subjectivity and initiative. Humans became active subjects able to consciously guide and reform things in positive adaptation to the environment because they made their labor purposeful. Meanwhile, in the setting of labor's purposes, targets became objects. The rise of purposes means emergence of conscious activities, which is the internal basis of human survival activities' change from negative and passive behavior out of instinct to positive and active practice. "With positive adaptation arising from labor, such life trend was enhanced continuously (much more in quality than in quantity)"6.

As a result of the change in concept of historic subjectobject, Lukács' understanding of the role of consciousness also became more comprehensive. In his early years, consciousness, as understood by him, was mainly a kind of reflective rational knowledge such as class consciousness, but in his later years, Lukács elaborated on the functions and roles of consciousness more extensively in terms of man's objective relations, e.g. purposes and intentions in practice, etc. Consciousness was never attached to organic life as an irrelevant factor from the beginning. On the contrary, in the sense of its origin, it resulted from organic life's positive adaptation to the environment. The so-called historical subjects are people able to initiatively and consciously reform and influence objective things in positive adaptation to the environment.

Then are historical subjects with independence and initiative completely detached from the animal world? In Lukács' opinion, though detached from purely biological existence, man cannot completely get rid of the basis of his biological existence. In this sense, man can never stop his existence as a natural being. The natural quality is increasingly

5 Lukács: An Introduction to the Ontology of Social Existence, ibid, Page 267.

6 Lukács: An Introduction to the Ontology of Social Existence, ibid, Page 172. 


\section{Philosophy International Journal}

restrained by the social quality in social existence. Though the laws of man's biological existence have qualitatively changed as a result, they cannot be annulled completely. Therefore, subjects that evolved from the biosphere but are qualitatively different from the biosphere still maintain their biological quality in a certain sense. This is elaboration of objective reality in subjectivity in terms of the origin of man's material existence.

However, the key reason why people can become historical subjects is their initiative, which does not exclude objective reality. On the contrary, objective reality is initiative's material source. On the one hand, a feature of human practice is that it is an objective material activity; on the other hand, one typical feature of human practice is its initiative - purposeful, planned and foreseen.

From his early years to his later years, Lukács' concept of subjects and objects and the connotations of subjectivity both changed, but there was also a constant factor in such change: his consistent emphasis of subjective factors shows his basic philosophical view, i.e. in both the objective relationship between people and things and the objective relationship between subjects and objects, he opposed the view of mechanical economic determinism or simple material determinism and emphasized man's initiative in objective relations. This cognitive feature of Lukács was to a certain extent the essence of German classical philosophy carried forward by Hegel and Marx. In his later years, with the change in his concept of subjects and objects, his understanding of man's initiative was deepened in comparison with his early class nature. He saw objective restraint in man's initiative. This was an understanding of great realistic significance.

\section{Realistic Significance of Lukács' Later Concept of the Historicsubject-Object}

In his later years, Lukács had opportunities to proceed from man's social origin and the emergence of society to discuss the issue of subjectivity in man's historical formation and his subject-object relations calmly. When he not only understood society's material existence in the sense of objectification of subjects, but also understood laws of social development in the sense of objectification of subjects, his vision of making the issue of the subject-object of history ontological and his intention of establishing ontologic theory of social existence were already covered, perhaps because Lukács had familiar with some actual socialist countries, whose survival mechanisms, dianamic forces of development and other issues directed Lukács' research scope to the depths of social nature and made him adopt a more natural and objective attitude in understanding social existence and the essence of development. The transition from giving attention to class consciousness to analyzing social existence in the sense of ontology shows Lukács' broader research scope and deeper research level.

Lukács analyzed human consciousness and practice in the sense of ontology of social existence, took this feature as the most essential and important objective law for social existence, and deemed such objective law as a factor differentiating social existence and natural existence. In his opinion, inorganic existence follows the law of causality; organic existence follows what Kant called "unintentional intentionality". Such "intentionality" is an unconscious and spontaneous forced reaction to nature for the purpose of selfreproduction, while the essential difference between man's labor practice and the above two is that conscious purposes are brought into social existence. The factor of purposes was used to emphasize both the differences between social existence and natural existence and the regularity of social existence. However, he did not deny the limitation and dependency of purposes as contents of conscious activities as opposed to natural existence. In his opinion, no matter how the significance of purposes is emphasized, purposes cannot replace the law governing things in their regular movement.

Viewed from another perspective, conscious and purposeful activities themselves constitute laws governing social affairs' functioning and cannot change the essence of things' regular movement. In this sense, it is through setting of purposes that the causal series exerts effect. For example, man's labor practice is social practice of man for his natural existence. Causality in natural areas and purposes in social areas are interwoven in labor practice; therefore, man's labor practice brings causality and purposes into social existence.

On the one hand, man's conscious purposes are seen as different from animals' unintentional purposes and used to emphasize man's subjective factors; on the other hand, man's conscious and purposeful practice cannot change the laws governing the functioning of things. To prevent such understanding from being caught in natural fatalism again, Lukács also emphasized selective factors in purposes and subjected social existence to the inevitability of selection. While fully emphasizing the subjective role, he saw the inevitability of the laws governing the functioning of objective things.

Anyhow, Lukács put forward his own view on the basis of labor - the medium of subject-object differentiation and association and the human practice encompassing natural existence and social existence: the conscious activities of people having become subjects through setting purposes are not just ordinary reflective activities but positive adaptive thinking activities carried out by them for their production and reproduction, which not only manifest the value relationship between subjects and objects, but also have 


\section{Philosophy International Journal}

trends.

This means "conscious activities in people's selection of purposes are often manifested as sources of their initiative (and such 'phenomenon' is of course an objective factor of social existence that cannot be ignored), so the real basis of man's practice and existence can only be discovered in conformity with existence through it" ${ }^{\prime \prime}$. Therefore, in conscious labor practice, trends and value relations are united. People themselves manifest the value relationship between subjects and objects by positively adapting to the environment through purposeful labor.

Lukács included conscious activities into the scope of ontology of social existence through purpose setting in labor practice. This mode of thinking allowed people to make breakthroughs in understanding of traditional historical materialism in two aspects: first, emphasizing that the laws of social development contain subjective factors through elaborating on the factor of purposes in the course of social development; second, under the precondition of affirming the basic Marxist view that human consciousness does not determine man's social existence but is determined by man's social existence on the contrary, further summarizing it as: "thoughts are formed in the formation of man as special living existence and formed in the formation of society as special basis and result of man's essentially new typological attributes and features" ${ }^{8}$. The relationship between consciousness and social existence is not manifested in the form of direct and simple causality as is the case in the inorganic sphere, because social existence itself is subject to the inevitability of selection.

Though Lukács saw the relationship between consciousness and existence in the sense of epistemology and in the sense of social existence differently, he did not clearly demonstrate this distinctive feature, which is manifested as follows: in the area of epistemology, the primacy of existence over consciousness is an undeniable fact from the perspective of science, but in the area of social existence, it is also an undeniable fact that social existence cannot possibly exist before man's conscious practice. Lukács included the factor of purposes in human practice into the category of social existence to demonstrate this issue.

On the basis of emphasizing man's practiccal activity guided by conscious in social existence, Lukács criticized the vulgar view which deemed Marxism as economic materialism

\footnotetext{
7 Lukács: An Introduction to the Ontology of Social Existence, ibid, Page 22.

8 Lukács: An Introduction to the Ontology of Social Existence, ibid, Page 309 .
}

and understood economic laws as purely material laws as opposed to conscious activities. In his opinion, because social existence is procedural existence based on purpose setting and indispensable basic factors in purpose setting are necessarily conceptual, economic factors in social existence are not purely material things in the sense of physics or chemistry. Concepts and substances are interwoven. Though Lukács did not specifically analyze the connotations of conscious activities per se or his understanding of the connotations of consciousness was not comprehensive, his analysis fully shows that purely material movement and purely economic movement detached from conscious activities are both inexistent in social existence.

Lukács adjusted his research scope with the change of the historical background, but if we observe the core of his thoughts, we can obviously see the development of his thoughts was consistent in terms of internal logical relations despite change of the times. He always emphasized that the initiative of social and historical development lied in subjectivity, and took man's conscious activities as internal basis of such initiative. In his early years, he took class consciousness resulting from reflexive rational knowledge as decisive force changing real society initiatively. In his later years, he made a breakthrough in understanding the issue, i.e. not just understanding the internal basis of subjects' initiative in the sense of reflexive cognition but understanding subjects' initiative in the sense of conscious activities as a component of labor practice. This understanding is obviously much profounder than the early one.

In his early years, he understood class consciousness in the sense of rational reflection; in his later years, his understanding of consciousness in human practice had included internal objective restraint on the factor of consciousness. Such internal objective restraint manifested in the purposes of the labor process was used to analyze the essence and role of consciousness and show the intentionality of conscious activities restrained by objective factors. Lukács' analysis shows: human initiative not only arises from reflective cognition, but also is manifested as subjects' active adaptation to objects at a more immediate level. In conscious activities at this level, irrational conscious activities ${ }^{9}$ also play a very important role.

The evolution of the concept of the historical subjectobject in Lukács' later years and his demonstration of objective factors in subjectivity are obviously related to his experiences. They were put forward in light of mechanisms of driving forces behind social and economic development

9 Here irrationality refers to intentionality, will, desire and other factors in relation to rational thinking activities. 
under the conditions of socialist public ownership. In the system of Marx's early thoughts, he understood the essence of human labor at two levels: the first one is material production activities that people engage in for survival, demonstrating passivity - the objective origin of man's labor initiative; the second one is human labor activities' feature of liberty and consciousness, which is a unique characteristic of human activities as opposed to satisfaction of animals' sole need for survival and man's need for self-improvement and all-round development developed in labor activities, demonstrating the feature of man's initiative in the sense of freedom and self-discipline. According to Marx, human labor in capitalist society is alienated in different senses, and people can truly combine labor for survival and free and conscious activities only in communist (socialist) society after freeing themselves from the passive state of alienated labor.

Different from Marx and Engels, Lukács personally experienced socialist practice, especially after he arrived in the Soviet Union in 1930s. Distribution according to contribution under the conditions of public ownership was replaced by absolute egalitarianism to some extent, and mechanisms of sustainable driving forces behind economic development became an issue. Perhaps this is the real context under which Lukács paid attention to labor's purposes and included labor's purposes into the scope of ontology of social existence. Under the conditions of socialist public ownership, how to combine man's passive production activities needed for survival and initiative activities of self-improvement and self-development in real economic mechanisms to give full play to people's initiative and potential in a wider range has become a realistic issue yet to be studied theoretically. In this sense, Lukács' later thoughts are highly realistic. The social transformation of the Soviet Union and Eastern Europe and the reform of China confirmed the existence of such an issue many years later.

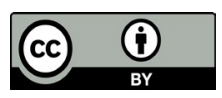

